The Bangladesh Veterinarian (2017) 34(2): 42 - 51

\title{
Prevalence and its influencing risk factors of subclinical mastitis in crossbred Friesian cows
}

\author{
SM Arman, MAN Al-Amin, MA Rahman, J Bhattacharjee and MMU Bhuiyan* \\ Department of Surgery and Obstetrics, Faculty of Veterinary Science, Bangladesh \\ Agricultural University, Mymensingh-2202, Bangladesh
}

\begin{abstract}
The prevalence and risk factors associated with subclinical mastitis in crossbred Friesian cows in selected dairy farms were studied using California Mastitis Test (CMT). A total of 287 cows and 1148 quarters were examined. Cow parity, age, body condition score (BCS), milk yield and lactation stage were collected by using pretested questionnaire. The prevalence of subclinical mastitis was $41.1 \%$. Among tested cows, $15.8 \%$ showed moderate and $5.5 \%$ strong reaction to $\mathrm{CMT}(\mathrm{P}<0.05)$. Among quarters, $24.6 \%$ quarters were affected with subclinical mastitis of which $10.1 \%$ showed moderate and $1.9 \%$ strong reaction to CMT $(\mathrm{P}<0.05)$. Cows at parity 2 to 4 had a significantly $(\mathrm{P}<0.05)$ higher prevalence $(46.5 \%)$ than those at parity 5 to $10(30.3 \%)$. The prevalence of subclinical mastitis in different age groups of cows did not vary significantly. The cows with BCS 3.5 to 4 had significantly $(\mathrm{p}<0.05)$ higher prevalence of subclinical mastitis $(43.5 \%)$ than those with BCS $4.5(25.9 \%)$. Cows with 11-27 litres of milk yield had significantly $(\mathrm{P}<0.05)$ higher subclinical mastitis (44.3\%) than that of 1 to 5 litres of their counterpart (38.6\%). Cows at 31 to 90 (44.3\%) days lactation had significantly $(\mathrm{P}<0.05)$ higher prevalence of subclinical mastitis than those at 181 to 285 days $(37.2 \%)$. It is suggested that the prevalence of subclinical mastitis was influenced by the parity, BCS, milk yield and lactation stage in crossbred Friesian cows in Bangladesh. (Bangl. vet. 2017. Vol. 34, No. 2, 42 - 51)
\end{abstract}

\section{Introduction}

Mastitis is an important disease causing economic loss to dairy industries of the world (Gill et al., 1990). Moreover, mastitis is the most common and costly production disease in dairying worldwide (Seegers et al., 2003; Halasa et al., 2007). The economic loss due to subclinical mastitis in USA was reported to be 1 billion US dollars annually (Ott, 1999) and 2 billion dollars annually in India (Joshi and Gokhale, 2006). In the Netherlands, losses due to clinical and subclinical mastitis varied between $€ 17$ and $€ 198$ per cow per year (Hogeveen et al., 2011). It was estimated that decreased milk yield due to sub-clinical mastitis caused losses of about 122.6 million Taka (US\$ 1 = 58.1 Taka) annually (Kader et al., 2003). For the dairy sector to be sustainable, it is necessary to control subclinical mastitis in cows. Subclinical mastitis can be detected by the measurement of inflammatory components and pathogens in the milk (Nielen et al., 1992). Subclinical mastitis often remains undetected by farmers, but can easily be detected by CMT (Schalm and Noorlander, 1957; Wesen et al., 1968). CMT is a rapid and inexpensive test to indirectly determine the somatic cell concentration in milk

\footnotetext{
*Corresponding author:- E-mail: mmubhuiyan@gmail.com
} 
(Midleton et al., 2004) and is a practical method for on farm milk sample testing (Dingwell et al., 2003).

The breed, age, parity, nutritional status, herd size, stage of lactation, morphology of udder and teat, milk yield, milking practice, water supply, barn size, residual suckling, udder towel and hygienic practice of dairy labourers have been identified as risk factors (Radostits et al., 2000; Kivaria et al., 2004). Several investigations were performed on clinical and subclinical mastitis in Bangladesh (Rahman et al., 2009; Rabbani and Samad, 2010; Rahman et al., 2010; Islam et al., 2011; Sarkar et al., 2013). A large population of Friesian crossbred cows has been developed and farmers are interested to rear them, and to improve their adaptability to hot and humid conditions in Bangladesh. The purpose of the study was to determine the prevalence and to identify risk factors influencing the prevalence of subclinical mastitis in crossbred Friesian cows in Bangladesh.

\section{Materials and Methods}

\section{Management of cows}

The cows were tied up in the barn and stall-fed mostly with straw, concentrates and green fodder with ad-libitum drinking water. The cows were dewormed and vaccinated regularly. The cows were hand milked twice daily keeping their calves at feet; however, during the last part of lactation, many farmers milked their cows once daily.

\section{Data collection from animals}

Data were collected from 287 crossbred Friesian cows from a large farm of Dhaka and 21 farms of Chittagong district. Data on parity, age, body condition score (BCS), milk yield and stage of lactation were gathered by using a pre-tested questionnaire. The questionnaire was filled in by interviewing the farmers and by examining the farm registers (if any) and the cows. Parity of cows ranged from 1 to 10. The age varied from 24 to 141 months. The BCS of cows was determined using a 1-5 scale $(0.5$ fractions between 2 scores) as described by Nicholson and Butterworth (1986). The daily milk yield ranged from 1 to 27 litres. The stage of lactation varied from 7 to 285 days.

\section{Determination of subclinical mastitis by California Mastitis Test (CMT)}

A total of 1148 quarters of 287 lactating cows were examined by CMT. The CMT was performed using 10\% Teepol (Leucocytest ${ }^{\circledR}$, Rhone Merieux, Lyon, France). Plastic paddle with four cups was used. After cleaning the teats and discarding several strips of milk, about $2 \mathrm{ml}$ of milk was taken from each teat. Two $\mathrm{ml}$ of reagent was added to each cup. The reagent and milk were mixed by swirling. Coagulation or gel formation of milk was regarded as positive for subclinical mastitis. The CMT reactions were categorised into (1) negative when the mixture remained fluid without thickening or gel formation, (2) trace when slight slime formation was observed (3) moderate when slime formation occurred immediately (4) distinct when distinct slime formation 
occurred after mixing the solution with milk and (5) strong when distinct slime formation occurred immediately.

\section{Experimental approaches}

On the basis of CMT reactions, subclinical mastitis was categorised as trace, moderate, distinct and strong. However, when any quarter had a positive reaction to CMT, the cow was considered as positive case of subclinical mastitis. To determine influence of parity, prevalence of subclinical mastitis was compared among 1, 2 to 4 and 5 to 10 parity cows. To determine influence of age, prevalence of subclinical mastitis was compared among cows of 24 to 36,37 to 72 and 73 to 141 months age. To determine influence of BCS, prevalence of subclinical mastitis was compared among 2.5 to 3, 3.5 to 4 and 4.5 BCS. To determine influence of milk yield, prevalence of subclinical mastitis was compared among cows yielding 1 to 5, 6 to 10 and 11 to 27 litres milk daily. To determine the influence of lactation stage, prevalence of subclinical mastitis was compared among cows at 7 to 30,31 to 90,91 to 180 and 181 to 285 days of lactation.

\section{Statistical analysis}

The collected data were entered in the Microsoft Excel ${ }^{\circledR}$ work sheet. Descriptive statistics were performed to find out the prevalence of subclinical mastitis. The data analysis was done by DMRT using SPSS 20 software to determine the influence of various risk factors on prevalence of subclinical mastitis. Differences were considered significant when the P value was less than 0.05 .

\section{Results and Discussion}

The prevalence and categories of subclinical mastitis are shown in Table 1. The prevalence of subclinical mastitis was $41.1 \%$ (287 cows were tested and 118 were positive). Similarly, $44.8 \%$ prevalence of subclinical mastitis was reported by Rahman et al. (2009) in Bangladesh, 40.1\% in Ethiopia (Birhanu et al., 2017) and 48.5\% in USA (Wilson et al., 1997). Higher proportion of cows affected with subclinical mastitis was also reported in Barisal district (51.6\%; Biswas and Sarker, 2017), Bangladesh Agricultural University (BAU) Dairy farm (57.0\%; Kader et al., 2002) and in Sarajevo, Bosnia-Herzegovina (63.3\%; Varatanovic et al., 2010). Lower prevalence of subclinical mastitis (15.1\%) in cows was reported in Bangladesh by Chowdhury (2011). Further, Prodhan et al. (1996) reported $15.8 \%$ prevalence of subclinical mastitis elsewhere. The reasons for variations may be due to variations in herd size, climate, management system and milking practices.

Among tested cows, 9.1\% cows showed trace, 15.8\% moderate, $10.8 \%$ distinct and $5.5 \%$ strong reaction to CMT. The difference was significant $(\mathrm{P}<0.05)$. Similarly, the highest proportion of cows showed moderate and the lowest proportion showed strong CMT reaction (Varatanovic et al., 2010). 
Table 1: CMT score of milk of cows affected with subclinical mastitis

\begin{tabular}{l|c|c|c}
\hline \multirow{2}{*}{ CMT Score } & No. of cows tested & \multicolumn{2}{c}{ Cows with subclinical mastitis } \\
\cline { 3 - 4 } & & No. & $\%$ \\
\hline Trace & 26 & $9.1^{\mathrm{b}}$ \\
Moderate & 45 & $15.8^{\mathrm{a}}$ \\
Distinct & 31 & $10.8^{\mathrm{b}}$ \\
Strong & 287 & 16 & $5.5^{\mathrm{c}}$ \\
Total & & 118 & $41.1^{1}$ \\
\hline
\end{tabular}

a,b,c Values with different superscript within same column varied significantly from each other $(\mathrm{P}<0.05)$.

The CMT reactions in different quarters are shown in Table 2. Overall, $24.6 \%$ (283 out of 1148) quarters had subclinical mastitis, of which $7.3 \%$ showed trace, $10.1 \%$ moderate, $5.3 \%$ distinct and $1.9 \%$ strong reaction to CMT. The difference between categories was significant $(\mathrm{P}<0.05)$. Similar proportion of quarters was affected with subclinical mastitis in crossbred dairy cows in Chittagong district of Bangladesh (27.0\%) (Jha et al., 2010). On the contrary, higher proportion of quarters was affected with subclinical mastitis in India (67.8\%) (Sharma et al., 2010). Moreover, 56\% quarter milk samples were positive to CMT in crossbred cows elsewhere (Ogola et al., 2007). Further, lower proportion of quarters $(16.1 \%)$ was affected in crossbred dairy cows in Ethiopia (Birhanu et al., 2017). The highest proportion of quarters (10.1\%) had moderate CMT score and the lowest proportion (1.9\%) had strong CMT score. Bhutto et al. (2012), however, reported the highest (20\%) proportion of quarters showed trace CMT score and the lowest (5\%) strong CMT score. Moreover, Kasikci et al. (2012) reported that the highest proportion $(66.9 \%)$ of quarters had trace CMT score $(+)$ and the lowest proportion $(11.1 \%)$ had strong CMT score $(+++)$. The variation may be due to different management practice, milking system and hygiene among farms.

Table 2: CMT score of quarter milk of cows affected with subclinical mastitis

\begin{tabular}{l|c|c|c}
\hline \multirow{2}{*}{ CMT Score } & No. of quarters tested & \multicolumn{2}{c}{ Cows with subclinical mastitis } \\
\cline { 3 - 4 } & & No. & $\%$ \\
\hline Trace & 84 & $7.3^{\mathrm{b}}$ \\
Moderate & 116 & $10.1^{\mathrm{a}}$ \\
Distinct & & 61 & $5.3^{\mathrm{c}}$ \\
Strong & & 22 & $1.9^{\mathrm{d}}$ \\
Total & 1148 & 283 & 24.6 \\
\hline
\end{tabular}

a,b,c,d Values with different superscript within same column varied significantly from each other $(\mathrm{P}<0.05)$. 
The influence of parity on prevalence of subclinical mastitis is shown in Table 3. The proportion of cows with subclinical mastitis was significantly $(\mathrm{P}<0.05)$ higher $(46.5 \%)$ at parity 2 to 4 than that at parity $1(40.9 \%)$ and parity 5 to $10(30.3 \%)$. Increasing parity is regarded as a risk factor for clinical and subclinical mastitis in cows (Dohoo et al., 1984; Schukken et al., 1993). Similarly, higher occurrence of subclinical mastitis was reported at 2 to 4 parity than at 1 parity (Biswas and Sarker, 2017). The prevalence of subclinical mastitis was higher in third and fourth lactation (19.1\%) followed by the second (16.1\%) and first lactation (6.2\%) (Prodhan et al., 1996). The prevalence of subclinical mastitis also significantly increased with increasing parities in crossbred dairy cows in Ethiopia (Birhanu et al., 2017). On the contrary, Hogan et al. (1989) found the highest occurrence of clinical mastitis in first lactation cows. However, it is difficult to conclude the reason for higher affection of subclinical mastitis in parity 2 to 4 as number of cows with parity 5 to 10 was few in the present study.

Table 3: The influence of parity on prevalence of subclinical mastitis in cows

\begin{tabular}{l|c|c|c}
\hline \multirow{2}{*}{ Parity of cows } & No. of cows tested & \multicolumn{2}{c}{ Cows with subclinical mastitis } \\
\cline { 3 - 4 } & & No. & $\%$ \\
\hline 1 & 52 & 21 & $40.9^{\mathrm{b}}$ \\
$2-4$ & 159 & 74 & $46.5^{\mathrm{a}}$ \\
$5-10$ & 76 & 23 & $30.3^{\mathrm{c}}$ \\
\hline
\end{tabular}

$a, b, c$ Values with different superscript within the same column varied significantly from each other $(\mathrm{P}<0.05)$.

The influence of age on prevalence of subclinical mastitis in crossbred Friesian cows is shown in Table 4 . The prevalence of subclinical mastitis among different age group cows varied from 39.1 to $42.9 \%$ and the difference in occurrence did not vary significantly $(\mathrm{P}>0.05)$ among the groups. Similarly, no difference in occurrence of subclinical mastitis was observed elsewhere (Biswas and Sarker, 2017). Contrasting to the present finding, Birhanu et al. (2017) reported higher occurrence of subclinical mastitis in crossbred dairy cows in Ethiopia in older animals. However, it is likely that increased age predisposes cows to more exposure to infection with mastitis pathogens and decreasing potency of the teat sphincter. Moreover, younger cows may have more effective host defence mechanism.

Table 4: The influence of age on prevalence of subclinical mastitis in cows

\begin{tabular}{l|c|c|c}
\hline \multirow{2}{*}{ Age of cows (months) } & No. of cows tested & \multicolumn{2}{|c}{ Cows with subclinical mastitis } \\
\cline { 3 - 4 } & & No. & $\%$ \\
\hline $24-36$ & 69 & 27 & 39.1 \\
$37-72$ & 126 & 54 & 42.9 \\
$73-141$ & 92 & 37 & 40.2 \\
\hline
\end{tabular}

Values within the same column did not vary significantly $(\mathrm{P}>0.05)$. 
The influence of BCS on prevalence of subclinical mastitis in crossbred Friesian cows is shown in Table 5. The prevalence was $41.3 \%$ in cows with BCS 2.5 to $3.0,43.5 \%$ in cows with BCS 3.5 to 4 and $25.9 \%$ in cows with BCS 4.5. The difference between cows with 2.5 to 4 and 4.5 BCS groups was significant $(\mathrm{P}<0.05)$. Atasever and Erdem (2009) reported a negative correlation between BCS at calving and Somatic Cell Score (SCS) of milk. However, De et al. (2011) reported no significant association between BCS at calving and SCS of milk. In contrast to our findings, no influence of BCS was reported on prevalence of subclinical mastitis elsewhere (Birhanu et al., 2017). It is likely that cows with high BCS had strong host defence against pathogens.

Table 5: The influence of BCS on prevalence of subclinical mastitis in cows

\begin{tabular}{l|c|c|c}
\hline \multirow{2}{*}{ BCS of cows } & No. of cows tested & \multicolumn{2}{|c}{ Cows with subclinical mastitis } \\
\cline { 3 - 4 } & & No. & $\%$ \\
\hline $2.5-3.0$ & 92 & 38 & $41.3^{\mathrm{a}}$ \\
$3.5-4.0$ & 168 & 73 & $43.5^{\mathrm{a}}$ \\
4.5 & 27 & 7 & $25.9^{\mathrm{b}}$ \\
\hline
\end{tabular}

a,b Values with different superscript within same column varied significantly from each other $(\mathrm{P}<0.05)$.

The influence of milk yield on prevalence of subclinical mastitis in crossbred Friesian cows is shown in Table 6. The cows with 11-27 litres milk yield had significantly $(\mathrm{P}<0.05)$ higher $(44.3 \%)$ prevalence of subclinical mastitis than those were giving 1 to 5 litres (38.6\%). This result is in agreement with earlier finding (Chassagne et al., 1998). Similarly, higher occurrence of subclinical mastitis was reported in cows with higher milk yield than in those with lower yield in Barisal district (Biswas and Sarker, 2017). On the contrary, no difference in prevalence of subclinical mastitis was demonstrated in crossbred dairy cows in Ethiopia when compared between $>15$ and $<15$ litres milk yield groups (Birhanu et al., 2017). The differences among studies may be due to variation in management practice, milking system and level of hygiene among farms.

Table 6: Milk yield and prevalence of subclinical mastitis in cows

\begin{tabular}{l|c|c|c}
\hline $\begin{array}{c}\text { Milk yield of cows } \\
\text { (Litres/day) }\end{array}$ & No. of cows tested & \multicolumn{2}{|c}{ Cows with subclinical mastitis } \\
\cline { 3 - 4 } & & No. & $\%$ \\
\hline $1.0-5.0$ & 57 & 22 & $38.6^{\mathrm{b}}$ \\
$6.0-10.0$ & 151 & 61 & $40.4^{\mathrm{ab}}$ \\
$11.0-27.0$ & 79 & 35 & $44.3^{\mathrm{a}}$ \\
\hline
\end{tabular}

$\mathrm{a}, \mathrm{b}$ Values with different superscript within same column varied significantly from each other $(\mathrm{P}<0.05)$.

The influence of lactation stage on prevalence of subclinical mastitis in crossbred Friesian cows is shown in Table 7. The cows at 7 to 30 (43.2\%), 31 to $90(44.3 \%)$ and 91 
to $180(41.7 \%)$ days lactation had significantly $(\mathrm{P}<0.05)$ higher prevalence than those at 181 to 285 days (37.2\%). This result is in agreement with earlier findings (Rahman et al., 2009; Jha et al., 2010). The high rate of subclinical mastitis during this stage of lactation might be due to peak level of milk production, which favours chances of contamination with microorganisms where hygiene is poor.

Table 7: The influence of lactation stage on prevalence of subclinical mastitis in cows

\begin{tabular}{l|c|c|c}
\hline \multirow{2}{*}{$\begin{array}{c}\text { Lactation stage of } \\
\text { cows (days) }\end{array}$} & No. of cows tested & \multicolumn{2}{c}{ Cows with subclinical mastitis } \\
\cline { 3 - 4 } & & No. & $\%$ \\
\hline $07-30$ & 37 & 16 & $43.2^{\mathrm{a}}$ \\
$31-90$ & 61 & 27 & $44.3^{\mathrm{a}}$ \\
$91-180$ & 103 & 43 & $41.7^{\mathrm{a}}$ \\
$181-285$ & 86 & 32 & $37.2^{\mathrm{b}}$ \\
\hline
\end{tabular}

a,b Values with different superscript within same column varied significantly from each other $(\mathrm{P}<0.05)$.

\section{Conclusions}

It may be concluded that the prevalence of subclinical mastitis was $41.1 \%$ and prevalence of subclinical mastitis is influenced by the parity, BCS, milk yield and lactation stage in crossbred Friesian cows in Bangladesh.

\section{Acknowledgements}

The authors express their special gratitude to International Atomic Energy Agency (IAEA), Vienna, Austria for financial support (CRP D31028, Contract No: 20654).

\section{References}

Atasever S, Erdem H 2009: Association between subclinical mastitis markers and body condition scores of Holstein cows in the Black Sea Region, Turkey. Journal of Animal and Veterinary Advances 8 476-480.

Bhutto AL, Murray RD, Woldehiwet Z 2012: California mastitis test scores as indicators of subclinical intra-mammary infections at the end of lactation in dairy cows. Research in Veterinary Science 92 13-17.

Birhanu M, Leta S, Mamo G, Tesfaye S 2017: Prevalence of bovine subclinical mastitis and isolation of its major causes in Bishoftu Town, Ethiopia. BMC Research Notes 10767.

Biswas D, Sarker T 2017: Prevalence of subclinical mastitis at Banaripara Upazila, Barisal. Bangladesh Journal of Veterinary Medicine 15 21-26.

Chassagne M, Barnouin J, Chacornac JP 1998: Biological predictors for early clinical mastitis occurrence in Holstein cows under field condition in France. Preventive Veterinary Medicine 35 29-38. 
Chowdhury MK 2011: Epidemiology of bovine mastitis in Bangladesh. PhD Thesis, Department of Surgery and Obstetrics, Faculty of Veterinary Science, Bangladesh Agricultural University, Mymensingh, Bangladesh.

De K, Mukherjee J, Prasad S, Dang AK 2011: Effect of different physiological stages and managemental practices on milk somatic cell counts of Murrah buffaloes. Buffalo Bulletin 30 72-74.

Dingwell RT, Leslie KE, Schukken YH, Sargeant JM, Timms LL 2003: Evaluation of the California mastitis test to detect an intramammary infection with a major pathogen in early lactation dairy cows. Canadian Veterinary Journal 44 413-415.

Dohoo IR, Martin SW, Meek AH 1984: Disease, production and culling in Holstein Friesian cows. VI. Effects of management on disease rates. Preventive Veterinary Medicine 3 15-28.

Gill R, Howard WH, Leslie KE, Lissemore K 1990: Economics of mastitis control. Journal of Dairy Science 73 3340-3348.

Halasa TK, Huijips K, Osteras O, Hogeveen H 2007: Economic effects of bovine mastitis and mastitis management: a review. Veterinary Quarterly 29 18-31.

Hogan JS, Smith KL, Hoblet KH, Todhunter DA, Schoenberger PS, Hueston WD, Pritchard DE, Bowman GL, Heider LE, Brockett BL, Conrad HR 1989: Bacterial counts in bedding materials used on nine commercial dairies. Journal of Dairy Science 72 250-258.

Hogeveen H, Huijps K, Lam TJG 2011: Economic aspects of mastitis: new developments. New Zealand Veterinary Journal 59 16-23.

Islam MA, Islam MZ, Islam MA, Rahman MS, Islam MT 2011: Prevalence of subclinical mastitis in dairy cows in selected areas of Bangladesh. Bangladesh Journal of Veterinary Medicine 9 73-78.

Jha AK, Hoque MN, Kamal MM, Rahman MM, Bhuiyan MMU, Shamsuddin M 2010: Prevalence of mastitis and efficacy of different treatment regimens on clinical mastitis in cows. SAARC Journal of Agriculture 8 79-89.

Joshi S, Gokhale S 2006: Status of mastitis as an emerging disease in improved and peri urban dairy farms in India. Annals of New York Academy of Science 1081 74-83.

Kader MA, Samad MA, Saha S, Taleb MA 2002: Prevalence and etiology of subclinical mastitis with antibiotic sensitivity to isolated organisms among milch cows in Bangladesh. Indian Journal of Dairy Science 55 218-223.

Kader MA, Samad MA, Saha S 2003: Influence of host level factors on prevalence and economics of subclinical mastitis in dairy milch cows in Bangladesh. Indian Journal of Dairy Science 56 235-240.

Kasikci GO, Cetin EB, Bingol M, Gunduz C 2012: Relation between electrical conductivity, somatic cell count, California mastitis test and some quality parameters in the diagnosis of subclinical mastitis in dairy cows. Turkish Journal of Veterinary and Animal Science 36 49-55. 
Kivaria FM, Noordhuizen JPTM, Kapaga AM 2004: Risk factors associated with subclinical mastitis in smallholder dairy cows in Tanzania. Tropical Animal Health and Production 36 581-592.

Midleton JR, Hardin D, Steevens B, Randle R, Tyler JW 2004: Use of somatic cell counts and California mastitis test results from individual quarter milk samples to detect subclinical intramammary infection in dairy cattle from a herd with a high bulk tank somatic cell count. Journal of American Veterinary Medical Association 224 419-423.

Nicholson MJ, Butterworth MH 1986: A guide to condition scoring of zebu cattle. International Livestock Centre for Africa, Addis Ababa, Ethiopia. pp. 1-29.

Nielen M, Deluyker H, Schukken YH, Brand A 1992: Electrical conductivity of milk: measurement, modifiers and meta-analysis of mastitis detection performance. Journal of Dairy Science 75 606-614.

Ogola H, Shitandi A, Nanua J 2007: Effect of mastitis on raw milk compositional quality. Journal of Veterinary Science 8 237-242.

Ott S 1999: Costs of herd-level production losses associated with sub-clinical mastitis in US dairy cows. Proceeding of $38^{\text {th }}$ Annual Meeting of National Mastitis Council, Arlington, VA. pp. 152-156.

Prodhan MA, Kamal AHM, Mahbub-E-Elahi ATM 1996: Prevalence of subclinical mastitis in cows of Bangladesh Milk-shed area. Bangladesh Veterinary Journal 30 59-61.

Rabbani AFMG, Samad MA 2010: Host determinants based comparative prevalence of subclinical mastitis in lactating Holstein-Friesian cross cows and Red Chittagong cows in Bangladesh. Bangladesh Journal of Veterinary Medicine 8 17-21.

Radostits OM, Gay CC, Blood DC, Hinchcliff KW 2000: Mastitis. In: Veterinary Medicine, 9th edition, W. B. Saunders Co., Philadelphia, pp. 603-612.

Rahman MA, Bhuiyan MMU, Kamal MM, Shamsuddin M 2009: Prevalence and risk factors of mastitis in dairy cows. The Bangladesh Veterinarian 26 54-60.

Rahman MM, Islam MR, Uddin MB, Aktaruzzaman M 2010: Prevalence of subclinical mastitis in dairy cows reared in Sylhet district of Bangladesh. International Journal of Bio-Research 1 23-28.

Sarkar SC, Parvin MS, Rahman AKMA, Islam MT 2013: Prevalence and risk factors of subclinical mastitis in lactating dairy cows in north and south region of Bangladesh. Tropical Animal Health and Production 45 1171-1176.

Schalm O, Noorlander O 1957: Experiments and observations leading to development of California mastitis test. Journal of American Veterinary Medical Association 130 199-204.

Schukken YH, Vanvlient J, Vangegeer D, Grommers J 1993: A randomized blind trial on dry cow antibiotic infusion on a low somatic cell count herd. Journal of Dairy Science 76 2925-2930.

Seegers H, Fourichon C, Beaudeau F 2003: Production effects related to mastitis and mastitis economics in dairy cattle herds. Veterinary Research 34 475-491. 
Sharma N, Pandey V, Sudhan NA 2010: Comparison of some indirect screening tests for determination of subclinical mastitis in dairy cows. Bulgarian Journal of Veterinary Medicine 13 98-103.

Varatanović N, Podžo M, Mutevelić T, Podžo K, Čengić B, Hodžić A, Hodžić E 2010: Use of California mastitis test, somatic cells count and bacteriological findings in diagnostics of subclinical mastitis. Biotechnology in Animal Husbandry 26 65-74.

Wesen DP, Luedecke LO, Forster TL 1968: Relationship between California Mastitis Test reaction and bacteriological analysis of stripping samples. Journal of Dairy Science $\mathbf{5 1}$ 679-684.

Wilson DJ, Gonzalez RN 1997: Evaluation of milk culture, SSC and CMT for screening herd additions. Proceeding of $36^{\text {th }}$ Annual Meeting of National Mastitis Council, Madison, WI. pp. 127-131. 